\title{
Mesai İçi ve Dışı Boş Zaman Davranışlarının Yönetimi: Teorik Çerçeve
}

\author{
Ebru AYKAN ${ }^{1}$ ve Zübeyir ÖZÇELİK ${ }^{2}$
}

\section{Öz}

Boş zaman davranışlarının yönetimi, yöneticilerin çoğu zaman ihmal ettiği ancak çalıșan performansıyla ilișkili olan önemli konulardan birisidir. Bu çalışmada; çalışanlar mesai içerisinde neden boş zaman davranışları sergilemektedirler? Yöneticiler mesai içinde oluşan boş zaman davranışlarına nasıl yaklaşmalıdır? sorularına cevap aranarak kavramsal bir çerçeve oluşturmak amaçlanmıștır. Çalıșanların mesai saatleri içerisinde kendilerine boș zaman oluşturmak istemelerinin nedenleri belirlendiği takdirde çalışanların boş zamanlarının etkili biçimde yönetilmesi ve bireysel performansın artırılması mümkündür. Bu çalışma, üç ana bölümden oluşmaktadır. Birinci bölümde; boş zaman kavramının geçmişi tarihsel süreç içerisindeki gelişimi ve yaklaşımları teorileriyle ele alınmıştır. İkinci bölümde mesai içerisinde çalışanların kendilerine boș zaman oluşturmak istemesinin nedenleri; yayılma teorisi, telafi teorisi, psikolojik ayrılma, kaynakların korunması, dikkat toplama ve güç - iyileşme teorileri ele alınarak incelenmiştir. Ayrıca bu bölümde mesai içi boş zaman, mesai dışı boş zaman kavramları detaylıca ele alınmıştır. Son olarak üçüncü bölümde ise işletme yöneticilerine ve bu konularda araştırma yapmak isteyen araştırmacılara mesai içinde ve dışında gerçekleşen boş zaman davranışlarının nasıl ele alınabileceğine dair önerilerde bulunulmuştur.

Anahtar Kelimeler: Boş Zaman Davranışları, Mesai İçi Boş Zaman Davranışları, Mesai Dışı Boş Zaman Davranışları

\section{Management of Workplace and out of Workplace Leisure Behaviors: Theoretical}

\section{Framework}

\section{Abstract}

Management of leisure behaviors is one of the important issues that managers often neglect but it is related to employee performance. Why are employees exhibiting leisure activities during work? How managers should approach the leisure behaviors within working hours. Basic aim of this study is to find solutions to these questions. If the reasons for the employee's desire to constitute leisure in working hours are determined, the leisure behaviours of the employees will be managed successfully. This study consists of three main parts. In the first part, scientific research field development and historical development of leisure concept are discussed with indifferent approaches. In the second part of the work, the causes of leisure behaviors of employees in the work were investigated by considering theory of spillover, compensation, psychological distraction, conservation of resources theory, attention restoration theory and effort recovery model. In the third part of the study, proposals were also made about how to manage leisure behaviors both in and out of the work place for business managers and researchers who want to conduct research in these subjects.

Key Words: Leisure Behaviours, Workplace Leisure Behaviours, Out of Workplace Leisure Behaviours

\section{Atıf İçin / Please Cite As:}

Aykan, E. ve Özçelik, Z. (2020). Mesai içi ve dışı boş zaman davranışlarının yönetimi: Teorik çerçeve. Manas Sosyal Arasttrmalar Dergisi, 9(1), 590-604.

Geliş Tarihi / Received Date: 17.12 .2018

Kabul Tarihi / Accepted Date: 16.09.2019

\footnotetext{
1 Doç. Dr. - Kayseri Üniversitesi, aykane@erciyes.edu.tr ORCID: 0000-0003-3537-5235

2 Dr. - Türkiye İstatistik Kurumu Başkanlığı, zubeyirozcelik@tuik.gov.tr ORCID: 0000-0001-7027-7396
} 


\section{Giriş}

Örgütler, rekabet avantajı elde etmek için rakiplerinin taklit etmesi güç olan farklı yetkinlikleri geliştirmek isterler. Bu yetkinlikler, günümüzde insan kaynağı üzerinde yoğunlaşmaktadır. Taklit edilmesi zor olması nedeniyle insan kaynağı işletmeler için stratejik bir rol oynamaktadır. Örgütler için insan kaynağının önemli olması, akademisyenleri ve örgüt yöneticilerini çalışanların alg1, tutum ve davranışları ile duygularını ve düşüncelerini anlamaya, öğrenmeye dönük araştırmalar yapmaya yönlendirmiştir.

Örgüt yöneticilerinin insan kaynağını iyi yönetebilmesi için onları iyi yönlendirebilmesi gerekmektedir. $\mathrm{Bu}$ bağlamda, örgütlerde öne çıkan kavramlardan biri de boş zaman davranışlarının yönetimidir. Örgütlerde boş zaman davranışlarının yönetimi örgüt yöneticilerinin çoğu zaman ihmal ettiği ancak çalışan performansıyla ilişkili olan önemli konulardan birisidir.

"Örgüt yöneticileri mesai içinde oluşan boş zaman davranışlarına nasıl yaklaşmalıdır?” sorusunun cevabı bu çalışmanın temel sorunsallarından birisini oluşturmaktadır. Sosyal psikoloji perspektifinden ele alındığında çalışanların mesai içinde kendilerine boş zaman oluşturmak istemelerinin nedeni teorik olarak bu çalışmada araştırılmıştır. Çalışanların mesai saatleri içerisinde kendisine boş zaman oluşturmak istemesinin nedenleri belirlendiği takdirde çalışanların boş zaman davranışları başarılı bir şekilde yönlendirilecek ve çalışanların performansı ve ruhsal sağlığı bu durumdan olumlu şekilde etkilenecektir. Bu kapsamda bu çalışmada boş zaman davranışları üzerine teorik bir çerçeve oluşturulması amaçlanmıştır.

Bu çalışma üç bölümden oluşmaktadır. Birinci bölümde, boş zamanın; tanımı, kapsamı, önemi, çeşitleri, literatürdeki gelişimi, ilişkili olduğu bilim dalları, örgütsel davranış ve yönetim organizasyon alanı ile bağlantılarına yönelik bilgilere yer verilmiştir. İkinci bölümde boş zaman ve iş arasındaki ilişki, mesai içi ve mesai dışı boş zaman kavramları ele alınmıştır. Ayrıca çalışanın mesai içinde kendisine boş zaman oluşturmak istemesinin nedenlerinin teorik altyapısını oluşturan; yayılma teorisi, telafi teorisi, psikolojik ayrılma, kaynakların korunması, dikkat toplama ve güç - iyileşme teorileri ikinci bölümde detaylı olarak incelenmiştir. Çalışmanın üçüncü ve son bölümünde ise literatürde konu ile ilgi gerçekleştirilmiş çalısmalara değinilmiş ve çalışma Sonuç ve Öneriler bölümü ile tamamlanmışır.

\section{Boş Zaman Kavramı ve Kapsamı}

Sosyal bilimlerde literatürde kullanılan leisure kavramı Türkçede boş zaman, serbest zaman olarak kullanılmaktadır (Gürbüz ve Henderson, 2013, s. 929). Leisure behaviours ise boş zaman davranışları olarak Türkçeye çevrilebilmektedir. Boş zaman üzerine literatürde yer alan birçok tanımlama bulunmaktadır. Boş zaman göreceli bir kavram olup, kültürden kültüre toplumdan topluma değişiklik göstermektedir.

NeumeyerveNeumeyer'e göre (1958, s. 17) boş zaman; güçlü ve pasif ilişkili olan günlük zorunlulukları gerektirmeyen ve firsatlar sunan bir faaliyet çeşididir. Dumazedier (1967, s. 55) boş zamanın; rahatlama, eğlence ve kendini geliştirme olmak üzere 3 fonksiyonu olduğunu belirtmiştir. Crandall (1979, s. 169), boş zaman kavramını herhangi bir güdüye dayandırılan ihtiyaçlar için harcanan serbest zaman olarak tanımlamıştır. Kelly’e göre (1994, s. 255) boş zaman kavramı, düşüncede hoşnutluk yaratan ve arzu edilen zamanı ifade etmektedir. Okumuş (2005, s. 26) boş zamanı insanların kendilerine ayırdığı özgür zaman olarak ifade etmektedir. Kılbaş (2010, s. 4) boş zamanı; kişinin çalışmadığı, yaşam zorunluluklarının ve biçimsel görevlerinin dişında kalan ve kendi isteği yönünde harcayabileceği zaman olarak belirtmektedir. Stebbins (2012, s. 19) ise, boş zamanı sekiz alt başlık altında tanımlamıştır:

1. Boş zaman, bir başka kişinin zorlaması olmadan yapılan bir faaliyettir,

2. Boş zamanın temelinde, katılımcının yapmak istediği faaliyetler vardır,

3. Boş zaman kavramı hoş olmayan zorlamalardan uzak geçirilen zamandır,

4. Boş zaman, sosyal bir kurumdur,

5. Boş zamanın kendi coğrafik bir uzayı vardır,

6. Boş zaman iş/yaşam dengesi için bir dayanak oluşturmaktadır,

7. Boş zaman insanın serbest vaktinde ne yaptığıyla ilişkilidir,

8. Boş zaman dünyada büyük ve geniş bir imaj oluşturur. Bilgi çağına geçişle birlikte boş zamanın önemi daha da artmıştır.

Boş zaman kavramını açıklayan tanımlamalar incelendiğinde aşağıda sunulan dört temel özellik dikkati çekmektedir: 
1. İş dışı zaman olması,

2. Sinirlamalardan uzak olmasi,

3. Faaliyetin özgür olarak seçilebilmesi,

4. İçsel motivasyon ve memnuniyet içermesi.

Bu tanımlamalardan yola çıkarak özgün bir boş zaman kavramı bireyin bir başkasının zorlaması olmaksızın tamamen özgür iradesini kullanarak ve kendi iç tatminini sağlayarak yaptığı/yapacağı bir faaliyet için tüketilen zaman şeklinde tanımlanabilir.

\section{Boş Zamanın Bilimsel Araştırma Alanının Gelişimi}

Boș zaman kavramı ve bilimsel araştırma alanının disiplinler arası gelişimi ve evrilmesi son 70 yllı kapsamaktadır. Araştırmalar genellikle zaman kullanım araştırmaları, bireylerin boş zaman faaliyetlerine katılımı, bireylerin boş zaman faaliyetlerini seçimleri ve sosyo psikolojik incelemeler üzerine yoğunlaşmaktadır (Henderson ve Bialeschki, 2007, s. 356). Boş zaman davranış bilimi, bireylerin boş zamanlarında neyi, ne için yaptığına ve gerçekleştirilen faaliyetlerin ekonomi, toplum gelişimi ve sağlı̆̆ına faydaları yönünden incelenmesine odaklanmaktadır (Caldwell, 2010, s. 8). Ayrıca yapılan bu çalısmalar ile ileride gerçekleşecek olan boş zaman faaliyetlerinin yönlendirilmesi de hedeflenmektedir.

Boş zaman çalışma alanı ilk önce Avrupa Üniversitelerinin sosyoloji alanında gelişmiş ve endüstri toplumlarında boş zamanın artmasıyla birlikte daha fazla ilgi çekmeye başlamıştır. (Godbey, Caldwell, Floyd ve Payne 2005, s. 151). Araştırmalar ilk aşamalarda günlük yaşamda zaman kullanımını ile şehirleşme ve endüstriyel alanlarda çalışma-boş zaman örüntüsünü incelemeye dönük gerçekleşmiştir. Daha sonraki zamanlarda ise, sosyal sınıflar, teknolojinin etkisi, boş zaman faaliyetlerinin çalışma yaşamında düzenlenmesi üzerine yapılmışıtır (Dumazedier, 1974, s. 133). Sosyoloji biliminde boş zaman üzerine yıllardır süre gelen dört temel soru bulunmaktadır (Kenneth, 2000, s. 3). Bu sorular;

1. İnsanlar ne kadar boş zamana sahiptir. Benzer şekilde sahip olunan bu boş zaman geçmiştekinden daha fazla mıdır? Hangi toplumların boş zamanı daha fazladır?

2. Sosyo-ekonomik gruplar arasında boş zamanın dağılımı nasıl ayrışmaktadır?

3. Boş zaman nasıl ve niçin kullanılmaktadır?

4. Hangi boş zamanlarda hangi faaliyetler gerçekleştirilmektedir?

Boş zaman çalışma alanı, sosyoloji, psikoloji, işletme, ekonomi, sağlık, felsefe, tarih, antropoloji gibi geleneksel birçok disiplinden faydalanmaktadır (Chick, 1998, s. 111), bu sebeple boş zaman çalışma alanı, disiplinler arası ve çoklu disiplinleri içeren bir araştırma alanından oluşmaktadır. Rojek'e göre (1997, s. 385) boş zaman yaklaşımları 2. Dünya Savaşından sonra üç farklı dönem geçirmiştir. 1. Dönem geleneksellik (1945-1975), 2. dönem yapisalcllı (1975-1990), 3. ve son dönemi ise 1990'dan günümüze gelen postmodernist dönem olarak ifade edilmektedir.

Teorisyenlerin boş zaman hakkındaki yaklaşımlanı ile Geleneksellik Dönemi, Yapısalcılık Dönemi ve Post-Modern Dönem olmak üzere üç farklı dönemin özellikleri Tablo 1'de verilmiştir.

Tablo 1. Boss Zaman Yaklaşım Dönemleri ve Kavramlar

\begin{tabular}{|c|c|c|c|}
\hline & Geleneksellik Dönemi & Yap1salcılik Dönemi & Post-Modern Dönem \\
\hline Teorisyenler & $\begin{array}{l}\text { Kelly, Dumazedier, Parker, } \\
\text { Roberts, Pieper De Grazia }\end{array}$ & $\begin{array}{l}\text { Deem, Woodward, Clarke ve } \\
\text { Critcher }\end{array}$ & Rojek, Moorhouse, Coalter \\
\hline $\begin{array}{l}\text { Dönem } \\
\text { Özeti }\end{array}$ & $\begin{array}{l}\text { Boş zaman ve faaliyetlerinin } \\
\text { tanımlanmaktadır. Bireyin } \\
\text { kendisini boş zamanda } \\
\text { hissetme düşüncesi, boş } \\
\text { zamana özgür seçim yaklaşımı } \\
\text { dönemin temel özelliklerini } \\
\text { göstermektedir. }\end{array}$ & $\begin{array}{l}\text { Boş zamanın tanımlanmasına } \\
\text { ihtiyaç hissedilmemiştir. Sosyal } \\
\text { süreçlere, sosyal yapılara, } \\
\text { sosyal grup ve farklılıklara } \\
\text { odaklanılmıstır. Boş zamana } \\
\text { ulaşımdaki eşitsizlikler } \\
\text { tanımlama yoluna gidilmiştir. }\end{array}$ & $\begin{array}{l}\text { Yaşam biçimi, tüketim } \\
\text { tarzlarının farkllıkları ile boş } \\
\text { zamana etkileri üzerinde } \\
\text { durulmuştur. Bireylerin boş } \\
\text { zaman farklılıkları, aktif ve } \\
\text { pasif boş zaman üzerine } \\
\text { odaklanılmıştır. }\end{array}$ \\
\hline Kavramlar1 & $\begin{array}{l}\text { Boş zaman tanımı, boş zaman } \\
\text { faaliyetleri, özgür seçim hakkı }\end{array}$ & $\begin{array}{l}\text { Boş zamana ulaşımdaki } \\
\text { eşitsizlikler, sosyal grupların } \\
\text { boş zaman farklılıkları }\end{array}$ & $\begin{array}{l}\text { Aktif ve pasif boş zaman } \\
\text { faaliyetleri, boş zaman } \\
\text { tüketimindeki farklllıklar }\end{array}$ \\
\hline
\end{tabular}

Kaynak: Demet Önder, ChangingGeography of Urban Leisure: The Case Of Ankara, Doctor of Philosophy in City andRegional Planning, Ankara, 2013, p. 18’ den uyarlanmıştır. 
Geleneksellik döneminde genel olarak boş zamanın ve boş zaman faaliyetlerinin tanımlanması üzerinde durulmuştur. Boş zamanın özgür bir seçim hakkı olduğu, bireyin boş zaman faaliyetini gerçekleştirirken kendisini tamamen özgür hissetmesi gerekliliği belirtilmiştir. Yapısalculık döneminde boş zamanın ne olduğu ile ilgilenilmemiştir. Bu dönemde, boş zamana ulaşımda sosyal gruplar arasındaki farklılıklar ve eşitsizlikler üzerinde durulmuştur. Post-modern dönemde ise boş zamana bakış açısında tüm sınırlama ve kısıtlamaların kalkması gerektĭgi üzerinde durulmuş, farklılık, çeşitlilik ve mobilite yaklaşımları ön plana çıkartılmıştır. Aşağıda boş zaman yaklaşımının değişim ve gelişim dönemleri detaylı olarak açıklanmaktadır.

\section{Geleneksellik Dönemi (1945-1975)}

Geleneksellik döneminde boş zaman kavramının tanımlanması, boş zaman faaliyetleri ve nerede meydana geldiği ile ilgilenilmiştir. Bu dönemdeki araştırmalar genellikle sosyal bütünleşme ve toplumu geliştirme bakış açısıyla boş zamanın pozitif etkileri üzerinde yoğunlaşmışıtır. Geleneksellik döneminin teorisyenlerinden; Roberts, Parker, Kelly ve Dumazedier boş zaman kavramını tanımlarken özgürlük, kendini gerçekleştirme, özgür seçim hakk1 gibi pozitif deneyimler (Önder, 2013, s. 18) üzerine yoğunlaşmışlardır. Bu dönem teorisyenlerinin ortak özellikleri boş zamanı çalışma olmayan zaman, zorunlu olmayan zaman olarak tanımlamalarıdır. Geleneksel dönemin savunucularının temel yaklaşımı iş ile boş zamanın birbirinden tamamen ayrıldığ (Wagner, Lounsbury ve Fitzgerald, 1989, s. 155) varsayımıdır. Bu yaklaşımın sebebi ise, bireyin aynı anda hem işte hem de boş zamanda olmasının mümkün olmadığı görüşüdür. Yine bu yaklaşıma göre iş ve boş zaman sınırları birbirinden keskin biçimde ayrılmıştır. Dumazedier (1967, s. 55) boş zamanı, iş, aile ve toplumu ilgilendiren bireysel zorunlulukların dışında, bireyin rahatlaması, eğlenmesi, bilgisini artırmasına yönelik, doğal sosyal katılımları içeren faaliyetler olarak tanımlamıştır. Kelly $(1983$, s. 5) boş zamanı, bir şeyin yapılması gerekiyorsa bu boş zaman değildir şeklinde tanımlamıştır. Kelly’nin, boş zamanı ne olmadığı üzerinden tanımlama yoluna gittiği görülmektedir. Parker (1976, s. 48) ise boş zamanı çalışma ve diğer zorunluluklardan uzak olma olarak tanımlamıştır. Geleneksel yaklaşım; boş zamana pozitif bir açıyla bakmış ve boş zaman ve faaliyetlerinin, mutlak suretle bireyler üzerinde olumlu bir izlenim bırakması gerektiğini belirtmiştir. Bu yaklaşıma göre birey eğer bir boş zaman faaliyetini gerçekleştirirken memnuniyet duymadıysa ve mutlu olmadıysa ilgili zamanın kötü bir şekilde geçirildiği ve tüketildiği gerekçesiyle, bu zaman dilimi boş zaman kapsamında değerlendirilmemektedir. Geleneksel dönemde boş zaman kavramı ve boş zaman yazın alanının yeni gelişmesi ve literatürde yeni araştırmalar yapılması nedeniyle bu dönemde, boş zamanın ne olduğu ve nasıl anlaşılması gerektiği üzerine yoğunlaşılmıştır.

\section{Yap1salc1lik Dönemi (1976-1990)}

Boş zamana geleneksel bakış açısı ile yaklaşan teorisyenler boş zamanı kendi iç dinamikleri olan bireyin özgürlüğ̈̈, bireyin kendisini gerçekleştirmesi ve özgür seçim hakk1 gibi konular üzerinden yorumlarken, yapısalcı yaklaşımla boş zamanı değerlendiren teorisyenler konuya ırk ve etnisite (Clarke ve Critcher, 1985, s. 6), cinsiyet farklılıkları (Scraton ve Watson, 1988, s. 125) gibi sosyal grupların boş zaman davranışları üzerinden yaklaşmışlardır. Geleneksel yaklaşım, boş zamanı ve faaliyetlerini yer ve zaman açısından belirli bir kalıpta sınırladığ için Clarke, Critcher ile Scraton, Watson gibi birçok yazardan eleştiri almışıtı. Dolayısıyla yapısalcı dönem teorisyenlerinin boş zamanın tanımlanması ve boş zaman faaliyetleri üzerinde durmadığ görülmektedir.

Yapısalcılık döneminde boş zaman faaliyetlerine ilişkin yapılan araştırmalarda toplumsal yapıyı oluşturan alt gruplar (cinsiyet, kültür, ırk, din, cemaatler, çocuklar, hastalar, yaşlılar, emekliler, engelli bireyler, LGBT grupları (Murray ve Nash, 2016, s. 6) üzerinde araştırmalar yapıldığı görülmektedir. Yapısalcılık döneminde, bireysel davranışlardan ziyade yapıların eşit olmadı̆̆ı üzerinde yoğunlaşma olmuştur. $\mathrm{Bu}$ dönemde farklı alt grupların boş zamana ulaşımdaki eşitsizlikleri üzerine araştırmalar yapılmıştır. Feministlerin boş zaman davranışlarının incelenmesi bu döneme örnek gösterilebilir. Clarke ve Critcher (1985); Rojek, (1989); Moorhouse (1989); Coalter (1989) gibi bu dönemin teorisyenleri kadınların boş zamanlarının erkeklerin baskın kontrolü neticesinde yönlendirildiğini ifade etmektedirler.

Clarke ve Critcher (1985, s. 35) tüm alt gruplara ait bireylerin içki içebileceğini, sigara kullanabileceğini, kumar oynayıp, televizyon izleyebileceğini belirtmektedir. Ancak bu bireylerin sayılan bu boş zaman faaliyetlerini nerede, ne zaman, nasıl ve hangi sosyal grubun şekillendirmesi ile yaptı̆̆ araştırmaların asıl sorunsalını oluşturmaktadır. Özetle bu dönemde belirli grupların boş zaman faaliyetleri üzerine odaklanma olduğu değerlendirilmektedir. 


\section{Post Modernist Dönem (1990 ve sonras1)}

Post modernist dönemde her gün bir diğer günden farklı olmakla birlikte olayların sonucunun tek, belirli bir sebebi olamayacağı, bireyin seçimlerinde tamamen özgür olduğu ve özgür iradesi ile karar vermesi gerektiği bakış açısıyla boş zaman teorileri ele alınmıştır. Boş zaman teorileri post modernist bakış açısıyla incelendiğinde; farklılık, çeşitlilik ve hareketliliğin ön planda olduğu görülmektedir (Henderson, Presley ve Bialeschki, 2004, s. 415). Post modernist dönemde otomasyonun ve makineleşmenin artmasından dolayı çalışanlar kendilerine iş dışında daha fazla boş zaman ayırabilmektedirler. Bu sebeple boş zaman kavramı ve boş zaman faaliyetleri bu dönemde daha da önem kazanmıştır. Post modernist dönemde maaşların ve ücretlerin sosyal olarak garanti altına alınması tüketim kültürünü ve boş zaman faaliyetlerine ayrılan parasal ekonomiyi de artırmaktadır (Rojek, 2010, s. 121). Postmodernist dönemde tüketim kalıplarının da değiştiği görülmektedir. Hatta post modernist dönem, tüketim kültürünün yoğunlaştı̆̆ tüketim toplumunun ortaya çıktığı bir sürecin ifadesi olarak da görülmektedir (Özcan, 2015, s. 15).

Bireyler bu dönemde geleceğin refahını hemen satın alma gayreti içerisine girmişlerdir. Post modern dönemde hedonist tüketim mantığ1 ortaya çıkmıştır. Hedonist tüketimin en belirgin özelliği kişinin elindeki nesnelerle yetinmemesi ve sürekli bir haz arayışı içinde olmasıdır (Özcan, 2015, s.16). Her ne kadar bireyler farklı şeylerden haz ve lezzet alma peşine düşseler de bu dönemde iletişim ve mobilitenin artmasıyla birlikte küresel eğlenceler, küresel etkinlikler, yeni toplumsal yaşamda kendisini göstermektedir.

Post modern dönemde boş zaman deneyimleri çoğunlukla hazzın tüketilmesini içeren konulu parklar, turistik mekânlar (Aytaç, 2002, s. 255), alış veriş merkezleri ve eğlence merkezlerinde yaşanmaktadır. Bu dönemde sanat ve spora yönelik sabır gerektiren uzun süreli faaliyetlerde azalma görülmektedir.

Rojeck (2010, s. 121) bu dönemde, boş zaman faaliyetlerini aktif ve pasif boş zaman faaliyetleri olarak 2'ye ayırmıştır. Aktif boş zaman faaliyetleri; sanatın, sporun, tiyatronun aktif olarak oyuncusu ve uygulayıcısı olmayı ifade ederken, pasif boş zaman faaliyetleri ise bunların izleyicisi olmayı ifade etmektedir. Dolayısıyla post modern dönemde televizyon izleme gibi pasif boş zaman faaliyetlerinin arttı̆̆1 gözlemlenmektedir. Aktif boş zamana katılım bireyin kendisini gerçekleştirmesi için, sağlık ve toplum için daha faydalı olduğu düşünüldüğunde post modern dönemdeki pasif boş zaman faaliyetlerinin artması bu dönemin olumsuz yönünü göstermektedir.

\section{Boş Zamanın Önemi}

Boş zamanlardaki faaliyetler ve meşguliyetler, hayatın ritmine katkıda bulunarak insanların deneyimlerini ve hayatla mücadele gücünü artırırlar (Fenech, 2008, s. 20). Bireyin boş zamanlarında planladığı boş zaman faaliyetlerini gerçekleştirmesi bireyin kapasitesini artırması ile bireye özgüven sağlar. Boş zaman faaliyetleri bireyin iyi oluşunu artırarak hayattaki stresi azaltmakla birlikte fiziksel ve ruhsal sağlığın sürdürülebilirliğini sağlamaktadır (Lu, Cheng ve Huang, 2015, s. 1432).

Boş zaman seçimi ve boş zamana katıllım, kişilik özelliklerinin gelişimini de etkilemekte ve bireye katkı sağlamaktadır (Mannell ve Kleiber, 1997, s. 36). Bireylerin boş zaman etkinliklerine katılmaları neticesinde bireylerin çevreyle etkileşimleri ile birlikte zihinsel durumlarında ve davranışlarında değişiklikler meydana gelmektedir (Kelly ve Freysinger, 2000, s. 79). Bu etkileşim ve çevresel faktörler kişiliği birçok yönden etkilemektedir (Mannell ve Kleiber, 1997, s. 78). Ayrıca boş zaman sosyal değişimin büyük bir parçası olabilir. Bazı insanların boş zamanlarında yaptığı faaliyetler toplum içerisinde değişim ve dönüşümlerin başlangıc1 olabilir ve boş zaman faaliyetleri toplum için sürükleyici bir rol üstlenebilir. Sivil toplum kuruluşlarının faaliyetleri bu değişim ve dönüşümlere örnek olarak gösterilebilir.

Kleiber, Hutchinson ve Williams (2002, s. 226) yaptıkları çalışmada; boş zaman davranışlarının, yaşama ilişkin olumsuz olaylarda, olumlu fonksiyonları olduğunu belirtmiştir. Bunlar;

1. Boş zaman faaliyetleri, bireyin dikkatini dağıtarak yaşanan olumsuz olayların etkisinin hissedilmesinde tampon görevi üstlenebilmektedir.

2. Boş zaman faaliyetleri bireyin geleceğe yönelik, iyimserliğini artırarak, bireyin yaşadığı olumsuz olayların etkisinin hissedilmesinde azaltıcı rol üstlenebilmektedir.

3. Boş zaman faaliyetleri bireyin kendisini yenilemesine olanak sağlamaktadır.

4. Boş zaman faaliyetleri bireyin kendisini dönüstürmesine olanak sağlamaktadır. 


\section{Boş Zamanın Yönetim ve Organizasyon Alanındaki Yeri}

Yönetim ve Organizasyon alanının gelişim sürecinde insanı birincil yapıda dikkate almayan klasik yönetim tarzından, insanı dikkate alan ve değer veren neoklasik yönetim tarzına geçilmiş ve daha sonra sistem yaklaşımına geçildiğinde ise örgütsel sistemi oluşturan en önemli yapılardan birisi insan unsuru olmuştur.

Kendini yöneten organizasyonlar, öğrenen organizasyonlar, amaçlara göre yönetim, proje bazlı yönetim, sanal organizasyonlar, şebeke organizasyonlar gibi çağdaş yönetim teknikleri incelendiğinde sonuç odaklı ve performans odaklı yönetim sistemlerinin günümüzde hâkim olduğu görülmektedir. $\mathrm{Bu}$ sistemlerde personeli motive edebilmenin temel yolu personeli kendi kararlarında serbest birakmaktır. Dolayısıyla günümüzde yöneticiler artık personelin belli bir zaman diliminde çalıștırılmasından ziyade sonuç odaklı ve performans odaklı çağdaş yönetim tekniklerini uygulamaktadırlar. Günümüz çağdaş yönetim tekniklerinde bireyin yapacağı iş, yönetici tarafından tanımlanmakta ancak bireyin işi gerçekleştirirken iş üzerindeki kontrol süreçlerine müdahale edilmemektedir.

Lambdin (1997, s. 26) kendini yönlendirerek öğrenme (self directed learning) kavramını şöyle açıklamıştır; bireylerin belirli bir amaca yönelik kendi planlı öğrenmeleri kapsamında kontrolün de kendilerinde olduğu süreçtir tanımdan da anlaşılacağı üzere öğrenme sürecini birey başlatmakta ve bu süreçteki kontrolünü de kendisi sağlamaktadır. Benzer şekilde boş zaman kullanımı da tamamen bireyin isteğine bağlı olarak tüm zorunluluklar ve kıstlamalardan uzak olarak bireyin kendisini yönlendirmesi doğrultusunda gerçekleşmektedir.

Boş zamanın kullanımı ve yönetimi kapsamında; kendini belirleme kuramı, kendini yönlendirerek öğrenme kavramı, kendini yöneten organizasyonlar, öğrenen organizasyonlar, amaçlara göre yönetim, proje bazlı yönetim, sanal organizasyonlar, şebeke organizasyonlar gibi çağdaş yönetim teknikleri bir bütün olarak incelendiğinde, yönetim ve organizasyon bakış açısıyla gerek işyerinde gerekse işyeri dışındaki zamanlarında çalışanın motive edilmesi yoluyla sevk ve idare edilmesinde çalışanların zaman yönetimi hususunda olabildiğince özgür karar vermesi ve bağımsız çalışma iradelerini ortaya koyması boş zamanın önemini artırmaktadır. Günümüzde teknolojinin gelişmesiyle birlikte özellikle beyaz yakalı çalışanların zaman kontrolü kendilerine geçmektedir. Pareto ilkesi olarak ifade edilen işte harcanan zamanın \% 20'si, sonuçların \% 80'ini oluşturduğu ve harcanan zamanın \% 80'i sonuçların \% 20'sini oluşturduğu (Scoot, 1995, s. 18) ilkesine göre, personelin belirli bir zaman diliminde kaç saat çalıştığından ziyade, belirli bir zaman diliminde planlanan hedeflere ne kadar ulaştı̆̆ örgütler için önem kazanmaktadır. Dolayısıyla mesai içinde ve dışında çalışanların gerçekleştirdiği boş zaman faaliyetleri ve bu faaliyetlerin bireysel performanslara etkisinin belirlenmesi yönetim ve organizasyon alanı için önem arz etmektedir.

\section{Boş Zaman ve İş Arasındaki İlişki}

Teorisyenler, boş zaman ve iş arasındaki ilişkiyi; boş zaman ve iş arasındaki benzerlikler ve farklılıkların ortaya konması üzerinden tanımlama yoluna gitmişlerdir. Boş zamana bakış açısında geleneksel yöntemi temsil eden teorisyenler (Stebbins, 1982, s. 254; Wagner, Lounsbury ve Fitzgerald, 1989, s. 156; Arai ve Pedlar, 1997, s. 168; Kelly, 1997, s. 133; Dumazedier 1974, s. 16) boş zaman ve iş arasında net bir ayrım yapılması gerektiği görüşünü savunmuşlardır (Önder, 2013, s. 18). Bu görüşe göre bireyin boş zamanı ve çalışmayı aynı anda beraber gerçekleştirmesi mümkün değildir. Birey aynı zaman diliminde çalışmakta veya boş zaman faaliyetine katılım sağlayarak alternatif bir tercih yapmaktadır. Kelly (1972, s. 50) boş zamanı, çalışma ile arasındaki farklı özellikleri açıklayarak tanımlama yoluna gitmiştir. Kelly'e göre çalışma, sosyal normlar gerektirmekle beraber, bireyin kendisi ve ailesi için bir ihtiyaçtır, ayrıca kazançlı ve gelir getirici bir olgu olarak tanımlanmaktadır. Boş zaman faaliyetleri ise gelir getirici değildir, statü ve hayatta kalmak için kaçınılmaz bir gerekçesi bulunmamaktadır. Dumazedier (1974, s. 133) boş zamanı bireyin yaratıcı kapasitesini artırmak amacıyla kendisi için zorunlu olan çalışmadan, aileden ve toplumdan uzak kalarak rahatlaması olarak ifade etmiştir. Parrv ve Long (1988, s. 36) boş zamanı, çalışma olmayan, zorunlu olmayan, sınırlandırılmamış zaman dilimi olarak tanımlamıştır.

Boş zamanı; faaliyetlerdeki farklılıklardan ziyade "state of mind" akıldaki bir durum, düşünce ve alg1lamadan ibaret olduğunu ifade eden baz1 yazarlar da (Stewart, 1998, s. 392; Samdahl, 1992, s. 19; Lee ve Dattiko, 1994, s. 196) bulunmaktadır. Bu yazarlara göre önemli olan bireyin kendisini boş zamanda hissetmesidir. Bu görüşün temsilcilerinden Samdahl (1992. s. 19) boş zamanı sadece hafta sonları veya akşamları ile kısıtlamanın doğru olmadığını belirtmektedir (Chua, 2001, s. 27). Benzer şekilde bu görüşün 
temsilcileri, boş zamanın herhangi bir zaman ve uzay dilimi ile bağlantısı olmadan bireyin algıladığı bir durum olduğunu belirtmektedir (Stewart, 1998, s. 392).

Edginton, DeGraaf, Dieser ve Edginton (2002, s. 48) ise boş zamana holistik (bütünleşik) bir bakış açısıyla yaklaşmışlardır. Holistik (bütünleşik) bakış açısına göre boş zaman; işin, eğitimin ve sosyal hayatın herhangi bir bölümünde bulunabilir. Çünkü boş zaman bunlarla yakın etkileşim içerisindedir ve birbirinden ayrilması zordur. Lee ve Dattiko (1994, s. 196), Russell ve Stage (1996, s. 110) ise boş zaman kavramının tek boyutta incelenmemesi gerektiği üzerinde görüş birliğinde bulunmaktadırlar. Boş zaman ve iş arasında net bir ayrım olduğunu desteklemeyen Wilensky (1960), Tait, Padgett ve Baldwin (1989, s. 505) gibi teorisyenler boş zaman ve iş arasındaki ilişkiyi yayılma teorisi ve telafi teorisi üzerinden açılama yoluna gitmişlerdir. Aşağıda bu iki teoriden bahsedilmektedir;

Yayılma Teorisi: Yayılma teorisi iş ve boş zaman arasındaki etkileşimi açıklamak için kullanılan en yaygın teoridir. Champoux (1978, s. 408) yaylmayı insanın doğası gereği iş deneyimlerinin insanı iş dışında da etkilemesi olarak ifade etmiştir. Kando ve Summers (1971, s. 14) yayllma kavramını çalışanın boş zamanında başka bir ifade ile iş olarak tanımlanmayan bir zaman diliminde işi ile meşgul olmasını işten boş zamana yayllım olarak ifade etmiştir. Bir doktorun mesai saati bitmesine rağmen akşam boş zamanlarında, herhangi bir sivil toplum kuruluşuna bağlı olarak maddi imkânı iyi olmayan hastaları ücretsiz tedavi etmesi işten boş zamana yayılım için verilebilecek güzel bir örnektir. Judge ve arkadaşları (1994, s. 102) yayılmayı, iş yaşamında mutsuz olan çalışanın boş zamanlarında da mutsuz olması ile ifade etmiştir. Yayılma teorisinde çalışan, iş zamanı ile boş zaman arasındaki sınırları çizmekte zorlanmaktadır.

Yayılma işten boş zamana doğru olabileceği gibi, boş zamandan işe doğru olacak şekilde çift yönlü olabilmektedir. Benzer şekilde aile ve boş zaman davranışları işi etkileyebileceği gibi çalışılan iş, aileyi ve boş zaman davranışlarını etkileyebilecektir (Kirchmeyer, 1992, s. 4).

İşte, teknolojinin yaygın kullanımı boş zaman ve iş arasındaki yayılımı artırmıştır. Lokasyonun iş yaşamında önemi gittikçe azalmışır, hatta bazı işler için kalmamışır da denilebilir. Çalışanlar evinde boş zamanlarda dinlenirken internetten işi ile ilgili yükümlülüklerini de yerine getirebilmektedirler (Lewis, 2003, s. 344). Bu sebeple bir faaliyetin boş zaman faaliyeti mi yoksa iş faaliyeti mi olduğuna karar vermek için yapılan işte amaç, niyet, memnuniyet ve motive edici etkenlere bakılması gerekmektedir.

Telafi Teorisi: Boş zaman ile iş arasındaki etkileşimi inceleyen telafi teorisi Chick ve Hood (1996, s. 333) tarafından geliştirilmiştir. Chick ve Hood çalışanın boş zaman faaliyetlerindeki seçiminin, mevcut işte yapmak istediği fakat yapamadığı faaliyetler üzerine odaklanmasını telafi teorisi olarak açıklamıştır. Edwards ve Rothbard (2000, s. 180) telafi teorisini, bireyin bir alandaki tatminsizliğini, diğer alana daha fazla odaklanarak veya o alana daha fazla zaman ayırarak telafi etme yoluna gitmesi olarak ifade etmektedirler. Champoux (1978, s. 403) ise telafi teorisini bireylerin bir alandaki eksik, problemli ve ödüllendirici olmayan davranış ve deneyimlerini başka bir alanda ödüllendirici davranışlarla telafi etmek istemeleri olarak ifade etmiştir. Örneğin, işte iş tatmini bulunmayan çalışanın, işyerinde işi ile ilgili olmayan farklı ilgi çekici davranışlar sergilemesi (Judge ve Watanabe, 1994, s. 102) telafi teorisi kapsamında değerlendirilebilir. Aynı şekilde çalışan işte yeterince ödüllendirildiğini ve mutlu olduğunu hissettiği takdirde, kendisini ödüllendirecek başka davranışların arayışı içerisine girmeyecektir (Faunce ve Dubin, 1975 aktaran Champoux, 1978, s. 403). Çalışanın kendisine işte boş zaman oluşturmak istemesinin birçok sebebi olabilir. Çalışan yaptığı işi zorluk derecesi az, yaratıcı olmayan, geliştirilebilir olmayan, mücadele gerektirmeyen bir yapıya sahip olduğunu düşündüğü takdirde telafi teorisi kapsamında işte kendisine boş zaman oluşturacaktır.

Bu çalısmada mesai içinde boş zaman kavramı ele alınırken, boş zamanı bireyin algıladığı bir durum olarak değerlendiren state of mind görüşü (Stewart, 1998, s. 392; Samdahl, 1992, s. 19; Lee ve Dattiko, 1994, s. 196) temel alınarak mesai içinde çalışanın kendisi için boş zaman olarak algıladığı bir durum olabileceği değerlendirilmiştir. Boş zaman kavramı literatürde mesai içi ve dışı boş zaman olarak incelenmektedir (Lebbon ve Hurley, 2012, s. 7). Aşağıda bu kavramlar açıklanmaktadır.

\section{Mesai İçinde Boş Zaman}

Çalışanların davranışlarını, duygularını, düşüncelerini öğrenme ile iş çevresinde yapılacak değişikliklerin çalışanlar üzerindeki etkilerinin incelenmesi 1933 yllındaki Hawthorne deneylerine (Trougakos, Beal, Green ve Weiss, 2008, s. 131) kadar dayanmaktadır. Çalışanlar mesai saatleri içerisinde kendilerine neden boş zaman oluşturmak istemektedirler? çalışanları boş zaman davranışlarına yönlendiren 
psikolojik sebepler nelerdir? gibi sorulara bu bölümde cevap aranarak mesai içinde boş zaman davranışlarının nedenleriyle ilgili teorik alt yapı incelenecektir.

Literatürde çalışanların mesai içinde kendisine boş zaman oluşturmak istemesini Ulrich, Dimbergve Driver (1989, s. 25) çalışanın kısa süreli olarak kendisini olumsuz olaylardan soyutlayarak dikkatini dağıtmak istemesi olarak açıklamışlardır. Etzion, Eden ve Lapidot (1998, s. 577) ise çalışanların mesai içinde kendisine boş zaman oluşturmak istemesini psikolojik ayrılma kavramı ile açıklamışlardır. Gervais (2014, s. 1), psikolojik ayrılma kavramını; çalışanın işten uzaklaşması, stresli ortamdan kurtulması, işe ara vermesi ve kendi sahip olduğu kaynakları yenilemesi olarak tanımlamaktadır. Benzer şekilde Iso-Ahola (1989, s. 10), boş zaman ve deneyimlerini bir kaçış ve çıkış olarak tanımlamıştır. Iwasaki ve Mannell (2000, s. 4) boş zaman faaliyetleri ile işten geçici olan uzaklaşmaların stresle baş edebilmek için bir çıkış noktası olduğunu belirtmektedir.

Newman, Tay ve Diener (2013, s. 556) boş zaman ve öznel iyi oluş arasında aracilık rolü olan psikolojik mekanizmaları incelediği çalışmasında, bireyin kendisine boş zaman oluşturarak işten uzaklaşmasını ve dikkatini dağıtmak istemesini aşağıda yer alan teorilere yapılan atıf sayılarını dikkate alarak açıklamışlardır.

- Kaynaklarin korunmasi teorisi (Conservation of resources (COR) theory), Hobfoll (1989)

- Güç-iyileşme modeli (Effortrecovery model), Meijman ve Mulder (1998),

- Dikkat toplama teorisi, (Attentionrestorationtheory), Kaplan (1995),

- Telafi teorisi (Compensationtheory), Chick ve Hood (1996),

- Yay1lma Teorisi (Spillovertheory), Kando ve Summers (1971).

Bu çalışmada çalışanın mesai içinde kendisine boş zaman oluşturma ve dikkatini dağıtarak işten uzaklaşmak istemesinin nedenleri ile yukarıda belirtilen teorilerin bağlantıları kurulmuştur. Yukarıda belirtilen bu teorilerden telafi teorisi ve yayılma teorisi önceki bölümde detaylı olarak ele alındığı için burada ayrıca ele alınmayacaktır, diğer teoriler ise aşağıda ele alınmaktadır.

\section{Kaynaklann Korunması Teorisi (Conservation Of Resources Theory)}

Hobfoll (1989, s. 513) tarafindan geliştirilen teori kapsamında bireyler kendi kaynaklarını oluştururlar, inşa ederler ve korurlar. Kaynakların korunması teorisinde kaynaklar; nesneler, zaman, koşullar, statüler, yatırımlar, enerjiler, özel ilişkiler, kişiler için önemli ve özel olan şeyler şeklinde tanımlanmıştır. Hobfoll'a göre bireyler kaynaklarını ve yatırımlarını kaybetme ile karşı karşıya kalmaları durumunda strese maruz kalmaktadırlar. Hobfoll'un teorisinde aşağıda belirtilen 3 koşuldan herhangi birisinin gerçekleşmesi durumunda birey psikolojik strese maruz kalmaktadır, bunlar; (1) bireyin sahip olduğu kaynakları kaybetme tehlikesiyle karşı karşıya kalması, (2) kaynakların kaybedilmesi, (3) diğer kaynakları harcamasına rağmen yeterli kaynağı elde etmede başarısız olunması. Hobfoll (2002, s. 307) kaynakları; maddi kaynaklar ve manevi kaynaklar olarak temelde 2 gruba ayırmıştır. Maddi kaynaklar; para, ev, evlilik, yiyecek ve benzeri şeylerdir. Manevi kaynaklar ise kişiye ait olan kişisel özellikler, sosyal destek, duygu ve enerji gibi soyut kavramlardır. Mesai içinde çalışanların pozitif duygu, düşünce, enerji, moral, motivasyon ve benzeri kişisel kaynaklarını kaybetmeleri mümkündür. Mesai içinde gerçekleştirilen boş zaman faaliyetleri ile çalşanlar arkadaşları ile sosyal ilişkilerini ve iletişimlerini artıırlar bunun neticesinde çalışanlar davranışlarında kendilerini kontrol etmelerini sağlarlar. Hobfoll (1989, s. 515) da sosyal kaynakları, aynı ilgi alanlarını paylaşan arkadaşlarla yakın ilişkilerde bulunmak olarak tarif etmiştir.

Sonnentag ve Fritz'e göre (2007, s. 204) kaynakların korunması teorisinde yeni kaynakların elde edilmesi ile birlikte zarar görmüş kaynakların restorasyonu mümkün olmaktadır. Dolayısıyla çalışanlar azalan kaynaklarını boş zaman faaliyetleri ile telafi etme imkânı bulmaktadıllar. Örneğin, Westman (1999, s. 25) aile ve arkadaşlarla geçirilen boş zamanın fiziksel ve duygusal kaynakları tekrar inşa ettiğini ve yeni kaynaklara ulaşmada yardımcı olduğunu, belirtmişsir. Boş zaman davranışları işten kısa süreli uzaklaşmalar sağlayarak çalışanın ruhsal olarak dinlenmesini sağlamakta ve fiziksel tükenmişliği azaltmaktadır. Moral, motivasyon, enerji, pozitif duygu, düşünce ve benzeri kaybedilen kaynakların geri kazanımı mesai içinde gerçekleştirilen boş zaman davranışları ile mümkün olmaktadır.

\section{Güç-İyileşme Modeli (Effort Recovery Model)}

Çalışanların maruz kaldıkları stres ve tükenmişliği azaltmak ve yok etmek için Meijman ve Mulder (1998, s. 55) güç-iyileşme (effort - recovery) modelini önermişlerdir. Modele göre çalışanın aşırı stres ve 
tükenmişlik yaşadığı durumlarda kalp atışı ile kan basıncı artar ve bunun neticesinde kardiyovaskuler sistemin düzenlenmesi için adrenalin salgılamasında artış görülür, bu durumda homoestaz denilen vücudun normal denge sistemi bozulur ve allostaz denen aşırı horman salgılanma durumu ortaya çıkar. Allostaz vücudun dengesinin sağlanması için vücudun geliştirdiği koruyucu bir sistemdir. Bu esnada salgılanan hormonların çok fazla olması bireyleri strese karşı korumaktan ziyade, beyne ve vücudun diğer kısımlarına zarar vermektedir (McEwen, 2006, s. 367). İyileşme süreci biyolojik olarak hormanlarıntekar normale dönmesi, tıp deyimiyle homoestoza dönüşmesini ifade etmektedir. Bireyin kendisini memnun edici ve ödüllendirici davranışlan, vücudun dengeye dönmesine (homoestoza) (Bodnarve Hadjimarkou, 2002, s. 1241) katkı sağlamaktadır. Ayrıca vücut sisteminin normale dönmesi için iyileşme denilen stresten uzak kalma aşamasının gerçekleşmesi gerekir (Meijmanve Mulder, 1998, s. 5). Geurts ve Sonnentag'a göre (2006, s. 482) iyileşme mesai içinde olabileceği gibi mesai dışında da gerçekleşebilir. Mesai içinde kısa süreli verilen molalarla çalısan kaybettiği enerjiyi geri kazanmaktadır.

İş yükünün ağır olması, gün içerisindeki mesai saatlerinin fazla olması, hafta sonları ve tatil günlerinde çalışma (Shamir, 1983, s. 98), çalışanın karar verme yetkisiniz az olması, artan iş talepleri çalışanın iyileşme (Sluiter, Beek ve Frings-Dresen,1999, s. 573)başka ifade ile normal yaşam düzenine dönme sürecine girmesi gerektiğinin göstergesidir. Çalışanların mesai içinde verdiği ara ve molalar iyileşme ve normale dönme sürecinin bir parçası olarak değerlendirilmelidir. Sonnentag (2001, s. 196) kitap okuma, arkadaşlarla etkileşimde bulunma ve egzersiz yapma gibi faaliyetleri içeren boş zaman davranışlarının iyileşmeyi kolaylaştırdığını belirtmiştir. Mesai içinde çalışanlar yoğun işyükü, artan yönetici talepleri, işte otonominin olmaması ve benzeri nedenlerle stres ve tükenmişliğe maruz kalmaktadır. Bu nedenle çalışanların kendi davranış düzenlemelerinde zaman zaman sorunlar yaşanabilmektedir. Yaşanan bu sorunların önüne geçilmesi için çalsşanların mesai içinde makul düzeyde kendilerine boş zaman ayırabilmeleri gerekmektedir.

\section{Dikkat Toplama Teorisi (Attention Restoration Theory)}

Stephan Kaplan (1989, s. 5) tarafindan geliştirilen dikkat toplama teorisinde; bireylerin dağılan dikkatlerinin manzara resimleri gösterme yoluyla tekrar toplanabileceği ifade edilmektedir. Birey bir uyarana karşı uzun süre odaklandığ1 takdirde kendisinde zihinsel yorgunluk oluşur ve bireyin bilişsel performansı azalmaktadır. Kaplan (2001, s. 169) dağılan dikkati toplamak için 4 farklı sürecin olduğunu belirtmiştir. Birinci süreç cą̧ibe veya çekicilike (fascination) dönemi olarak ifade edilmektedir. Bu dönemde birey bir uyarana karşı mental odaklanma amacı gütmez ve herhangi bir şekilde enerji harcanması da söz konusu değildir (Gavarkovs, 2015, s. 3). Bu dönemde uyaran beyne çekici gelmekte fakat uyaran, bireyin kendi amacı ile örtüşmemektedir. Kaplan bu süreçte çalışanın mevcut uğraşı̆̆g işten uzaklaşarak dikkatinin dağılmasının gerçekleştiğini, bu sebeple de zihinsel yorgunluğun giderildiğini ifade etmektedir. Kaplan teorinin ikinci sürecini uzak olmak (beingaway) olarak ifade etmiştir. Bu süreçte de bireyin mevcut bulunduğu ortamdan uzaklaşması veya başka bir çevrede bulunması gerekmektedir. Konu ile ilgili üçüncü süreç boyut (extent) olarak ifade edilmektedir. Bu süreçte birey dağılan dikkatini toparlamak için farklı manzara resimlerine bakar veya kapalı bir mekânda ise dişarıya bakar ve kendi dikkatini yeniler. Bu süreçte bireyin bulunduğu mekânı değiştirmesi gerekmektedir. Dördüncü ve son süreç ise uyumluluk (compatibilite) olarak ifade edilmektedir (Kaplan, 2001, p.1). Bu süreçte bireyin dikkatini dağıtarak tekrar toparlayabilmesi için bireye içinde bulunduğu duruma uygun olan resimler gösterilmelidir. Örneğin, zihinsel olarak yorgun olan bir bireye korkutucu veya çevreye ilişkin olumsuz fotoğraflar gösterilmesinin zihinsel yorgunluğu giderici yönde bir katkısı olmayacaktır.

Dikkat toplama teorisinde belirtildiği gibi çalışanların mesai içinde mevcut işini gerçekleştirmek için dikkatini belirli bir şey üzerinde odaklaması gerekmektedir. Bu dikkat toplama faaliyeti uzun sürdüğ̈̈ takdirde zihinsel yorgunluğa sebep olmaktadır. Çalışanların mesai içerisinde mevcut işinden kısa molalar aracıllğ̆yla kaçış sağlaması işteki dağılan dikkatlerini toplamada faydalı olmaktadır. Mesai içinde çalışanlar dağılan dikkatlerini toplamak için kendilerine ayırdıkları boş zamanlarında haber ve gazete okuyabilir, müzik dinleyebilir, hayal kurabilir, hafta sonu tatil planları vb. şeyler yapabilirler. Mesai içinde kısa süreli gerçekleşen işe ilişkin olmayan bu faaliyetler işteki performansa olumlu yansıyacaktır.

\section{Mesai Dışında Boş Zaman}

Mesai dışı boş zaman kavramı içerisinde çalısmayı net bir şekilde içermediği için boş zaman kavramına göre zihinlerde daha net bir çağrışım yapmaktadır. Mesai dışı boş zaman bireyin tamamen özgür ve bağımsız olduğu, çalışma haricindeki zamandır (İyem, 2011, s. 11) şeklinde ifade edilmektedir. Wilson'a göre (1980, s. 22) mesai dışındaki zaman diliminin tamamının boş zaman olarak değerlendirilmesi mümkün değildir. Çünkü mesai dışında da ev işleri, bireysel temizlik ve benzeri bireylerin gerçekleştirmesi 
gereken zorunlu faaliyetler bulunmaktadır. Bu kapsamda, Aydoğan (2000, s. 198) Serbest zaman ve boş zaman kavramlarını birbirinden ayırmıştır. Aydoğan'a göre birey sağlığı ve yaşamı için gerekli olan fizyolojik gereksinimleri, ailesi, toplumu ve ülkesiyle ilgili yükümlülüklerin hepsini boş zamanda yerine getirmektedir. Serbest zamanda ise, bu yükümlülüklerin dışında, bireyin sadece kendisi için, kendisi adına yaptığı etkinlikleri içine alan faaliyetleri gerçekleştirmektedir. Dolayısıyla mesai dışı boş zamanın; boş zaman diliminde gerçekleştirilen faaliyetler bireyin zorunlu olarak gerçekleştirmesi gereken faaliyetlerden oluşurken, serbest zaman diliminde gerçekleşen faaliyetler bireyin kendi hatırına, kendi isteğine göre yaptı̆̆ faaliyetlerden oluşmaktadır.

Mesai dışı zaman kavramsal olarak pratikte bir bütünü ifade etse de uygulamada birçok bileșenden oluşmaktadır. Dumazedier, Parker, Margyeri, Robinson, Tezcan, Meyer, Zuzanek gibi teorisyenler mesai dışı zamanın tamamen boş zaman olmadığına ilişkin görüş birliğinde (Tel, 2007, s. 35) bulunmaktadırlar. $\mathrm{Bu}$ teorisyenlere göre mesai dışı zaman temelde üç gruba ayrilabilir;

1. Temel ibtiyaçlarn giderilmesine aymlan zaman; ev işleri, ailesel görevler, alış veriş, yemek yemek, uyumak, vücut temizliği gibi şeyler için ayrılan zaman,

2. Calş̧ma ve buna bağh etkinlikler ve görevler için ayrlan zaman; iş, yolculuk, ödev, öğrenim için geçen süre vb.,

3. Kişiye özel olan zaman: içeriği iş ilişkisiyle belirlenmemiş olan zaman dilimini ifade etmektedir. Seçilen davranışlar serbestçe gerçekleştirilebilmektedir. Kişiye özel olan zaman; Parker'ın (1976, s. 48) bireyin hem kendisi, hem de başkaları için bütün zorunluluklardan kurtulduğu ve tamamen kendi özgür iradesi ile seçeceği bir faaliyetle uğraşacağı zaman tanımı ile örtüşmektedir.

Yukarıdaki gruplamalardan da anlaşılacağı üzere net olarak bireye ait serbest zaman kavramını ifade edebilmek için günlük 24 saatlik zaman diliminden; çalışma zamanını, çalışma ve buna bağlı etkinlikler ve görevler için ayrılan zamanı ve temel ihtiyaçların giderilmesine ayrılan zamanı çıkarmak gerekmektedir.

Mesai dışı boş zaman davranışlarının iş performansına etkisi iyileşme kavramı üzerinden açıklanmaktadır. Meijman ve Mulder (1998, s. 8) iyileşmeyi insan fonksiyonlarının stres öncesi normal duruma gelme süreci olarak ifade etmişlerdir. Zijlstra ve Sonnentag (2006, s. 129) ise çalışanların iyileşme sürecine psikolojik perspektiften bakmışlar ve çalışanların mevcut ve gelecekte kendilerinden beklenen işleri yapmaya hazır olma durumlarını iyileşme olarak tanımlamışlardır.

İşteki yoğun çalışma saatleri, işte ve iş dışında dinlenme ve iyileşme ihtiyacını ortaya koymaktadır. Dinlenme ve iyileşme, günlük olarak mesai içinde kahve molası, yemek molası, iş geçişleri arasındaki vakitlerin kullanımı, işte oluşan boş zamanların değerlendirilmesi ile gerçekleşirken (Pennonen, 2011, s. 14), iş dışında ise akşamları ve hafta sonlarında gerçekleşmektedir (Sluiter, Judith, Frings, Dresen, Meijman ve Beek, 2000, s. 298). Bununla birlikte iş stresi ve yorgunluğa dayalı olarak gerçekleştirilemeyen iyileşmeler uzun dönemde insan sağllğını olumsuz yönde etkilemektedir (VanHoof, Geurt, Taris, 2005, s. 5). Sonnentag ve Fritz (2007, s. 204) yaptıkları araştırmalarda hafta sonu dinlencelerinin iş performansı üzerinde olumlu etkileri olduğunu ölçmüşlerdir. Bu ölçümleme sonucunda çalışanların pazartesi günkü iş performanslarının, salı günkü iş performanslarından daha yüksek olduğu sonucuna ulaşılmıştır. Bunun sebebinin ise hafta sonlarında gerçekleşen boş zaman faaliyetlerinin çalışana enerji sağlaması olduğu tespit edilmiştir.

Mesai içinde verilen kısa molalar iyileşmeye katkı sağlarken gerçek iyileşme dönemi mesai dışında geçirilen boş zamanda gerçekleşmektedir. Akşamları ve hafta sonları gerçekleştirilen bireyi rahatlatıcı ve uyarıcı olan boş zaman faaliyetleri bireye iyileşme firsatı sunmaktadır (Pennonen, 2011, s. 15). Dolayısıyla mesai dışında gerçekleştirilen boş zaman faaliyetlerinin ne ile ve nasıl değerlendirildiği çalışanın işyeri performansının artırılması için önem arz etmektedir.

\section{Tartışma, Sonuç ve Öneriler}

$\mathrm{Bu}$ çalışmada çalışanların mesai içinde kendilerine boş zaman oluşturmak istemelerinin nedenleri kaynakların korunması teorisi, iyileşme modeli, dikkat toplama teorisi ile ilişkilendirilerek açıklanmıştır.

Kaynakların korunması teorisinde; çalışanın stres durumu ile karşı karşıya kalmaması için sahip olduğu duygu, enerji ve benzeri soyut kaynakların sürekliliğini koruması gerekmektedir. Çalışanlar mesai içi boş zaman davranışları ile işyerinde sahip oldukları soyut kaynakları koruyabilmektedirler. Nitekim Westman (1999, s. 13) yaptığ1 araştırmada; arkadaşlarla geçirilen boş zamanın fiziksel ve duygusal kaynakları tekrar inşa ettiğini ve yeni kaynaklara ulaşmada yardımcı olduğunu, belirtmiştir. Moral, 
motivasyon, enerji, pozitif duygu, düşünce ve benzeri kaybedilen kaynakların geri kazanımı mesai içinde gerçekleştirilen boş zaman davranışları ile mümkün olmaktadır.

İyileşme teorisinde; iş yükünün ağır olması, gün içerisindeki mesai saatlerinin fazla olması, hafta sonları ve tatil günlerinde çalışma (Shamir, 1983, s. 98), çalışanın karar verme yetkisiniz az olması ve artan iş talepleri nedenleriyle çalışanın iyileşme sürecine (Sluiter, Beek, Frings-Dresen, 1999, s. 573) başka ifade ile normal yaşam düzenine dönme sürecine girmesi gerektĭgi ifade edilmektedir. Çalışanların mesai içinde verdiği ara ve molalar iyileşme ve normale dönme sürecinin bir parçası olarak değerlendirilmelidir. Benzer şekilde Sonnentag (2006, s. 482) yaptığ araştırmada; kitap okuma, arkadaşlarla etkileşimde bulunma ve egzersiz yapma gibi faaliyetleri içeren boş zaman davranışlarının iyileşmeyi kolaylaştırdığını belirtmiştir.

Kaplan (2001, s. 8) tarafindan geliştirilen dikkat toplama teorisinde; çalışanların mesai içinde mevcut işini gerçekleştirmek için dikkatini belirli bir olgu üzerinde uzun süre odakladığı takdirde, çalışanlarda zihinsel yorgunluk oluştuğu belirtilmektedir. Çalsşanların mesai içerisinde mevcut işinden kısa molalar aracıllğıyla kaçış sağlaması işteki dağılan dikkatlerini toplamada faydalı olmaktadır. Benzer şekilde; Kanfer, Ackerman, Murtha, Dugdale ve Nelson (1994, s. 826) yaptıkları araştırmada, performans hedefi belirli olan işlerde verilen sık molaların, mola verilmeyenlere göre daha yüksek performans elde edilebildiğini belirtmektedirler.

Yukarnda açılanan teorilerden de yola çıkarak; örgüt yöneticileri mesai içinde oluşan boş zaman davranışlarına tümüyle olumsuz bir bakış açısıyla bakmamalıdır. Sosyal psikoloji perspektifinden ele alındığında boş zaman çalışanlar için bir ihtiyaç olarak görülmeli ve bireyin kendini yenilemesine ve mevcut işine veya bir sonraki işine daha iyi bir şekilde odaklanmasını sağlamaktadır. Trougakos, Beal, Green ve Weiss (2008, s. 131) hizmet sektöründe çalışanlar üzerinde yaptıkları araştırmada işte verilen molalarda çalışanların pozitif duygularının yüksek olduğu, negatif duygularının ise düşük olduğunu, ayrıca mola sonrası iş esnasında çalışanların yüksek pozitif duygu içerisinde olduklarını belirtmektedirler. Bu sonuçlara göre işte eğlence ile geçirilen dinlenme aralarının birey performansını olumlu yönde etkilediği değerlendirilmektedir. Dolayısıyla mesai içindeki boş zaman faaliyetlerinin çalışanın işle ilişkisini kısa süreli olarak kesmesi; çalışanlar için tansiyonu azaltan, işten kısa süreli kaçışlar sağlayan, çalışanı dinlendiren, geliştiren ve iş performansını olumlu etkileyen yönleri bulunmaktadır. Coker (2013, s. 115) mesai içinde verilen sık molaların uzun süreli verilen dinlenme aralarına oranla verimliliği daha fazla artırdığını belirtmektedir. Çalışma sonucunda örgüt yöneticilerine ilisskin öneriler aşağıda sunulmaktadır;

- Örgütlerde boş zaman kavramı bütüncül bir yaklaşımla ele alınmalı, özellikle mesai içi boş zaman davranışlarının sebepleri örgüt ve birey düzeyinde araştırılmalıdır.

- Örgütlerdeki mesai içi boş zaman davranışlarının, işte memnuniyetsizliğe ilişkin nedenlerden kaynaklandığ1 tespit edildiği takdirde kişi-iş uyumu, kişi örgüt uyumu gözden geçirilmelidir.

- Örgütlerdeki mesai içi boş zaman davranışlarının bir nedeninin de iş süreçlerindeki eksikliklerden kaynaklandığı unutulmamalı ve iş analizi ile iş süreçleri örgütlerde detaylı olarak çalışılmalıdır.

- Aile ve iş dışındaki etkenlerin bireyin iş yaşamını geçirgenlik teorisi kapsamında etkileyeceği unutulmamalıdır. Dolayısıyla yöneticiler, çalışanlarını aileleriyle geçirdikleri boş zamanlarını artırmaları yönünde telkinlerde bulunmalı ve çalışanlar için aileleri de içeren iş gezileri, piknikler ve sportif faaliyetlere önem vermelidirler.

Ayrıca örgüt yöneticileri mesai içinde oluşan boş zamanı, aşağıdaki davranış ve faaliyetlerle yönlendirerek çalışanın motivasyonuna katkı sağlayabilirler;

- İşte koçluk ve mentörlük faaliyetlerine önem vermek,

- Üstesinden gelmesi zor olan fakat gerçekleştirilebilir hedefler koymak,

- Çalışanların yetenek ve kabiliyetlerini geliştirici boş zaman faaliyetlerini desteklemek,

- Stres ve çatışmayı optimum düzeyde tutmak,

- Çalş̧ana, boş zaman ihtiyacina saygı duyulduğunu hissettirmek,

- Çalışan işi yaparken kendisi adına da bir şeyler yaptığını hissettirmek,

- Çalışanın özel yaşantısına değer verildiğini kendisine hissettirmek,

- Çalışanın hobilerine ve boş zamanlarına değer verildiğini hissettirmek.

Bu çalışmanın neticesinde oluşan sonuçlara göre daha sonra yapılacak olan yeni çalışmalarda; mesai saati içerisinde ne kadar süre ile gerçekleşen bir boş zaman diliminin iş performans üzerinde olumlu çıktılar 
elde edilebileceğine dair ölçümler yapılarak farklı araştırmalar yapılabilir. Ayrıca mesai içi ve dışı boş zaman faaliyetleri ile tükenmişlik ve stres gibi farklı değişkenler beraber çalışılabilir.

\section{Kaynakça}

Arai, S. M. ve Alison, M. P. (1997). Building communities through leisure: citizen participation in a healthy communities initiative. Journal of Leisure Research, 29 (2), 167-182.

Aydoğan, F. (2000). Medya ve serbest zaman. İstanbul: Om Yayinevi.

Aytaç, Ö. (2002). Boş zaman üzerine kuramsal yaklaşımlar. Frrat Üniversitesi Sosyal Bilimler Dergisi, 12(1), 231-260.

Bodnar, R. J. ve M. H. (2002). Endogenous opiates and behavior. Peptides, 24, 1241-1302.

Caldwell, L. (2010). Leisure and health: why is leisure therapeutic?. British Journal of Guidance \& Counselling, 33, 7-26.

Champoux, J. (1978). Perceptions of work and nonwork. Sociology of Work and Occupations, 5(4), 402-422.

Chick, G. ve Robert, D. H. (1996). Working and recreating with machines: outdoor recreation choices among machine tool workers in western pennsylvania. Leisure Sciences, 18(4), 333-354.

Chick, G. (1998). Leisure and culture: 1ssues for an anthropology of leisure. Leisure Sciences, 20(2), 111-133.

Chua, S. (2001). The Sociology of Leisure An Examination Of The Relationship Between Perceived Experience And Participation. Phd Thesis, 27.

Clarke, J. ve Chas C. (1985). The devil makes work: Leisure in Capitalist Britain. London: Macmillan.

Coalter, F. (1989). Leisure policy: an unresolvable dualism. In C. Rojek, Leisure for Leisure: Critical Essays, London: MacMillan.

Coker, B. L. S. (2013). Workplace internet leisurebrowsing. Human Performance, 26, 114-125.

Crandall, R. (1979). Social interaction, affect and leisure. Journal Of Leisure Research, 11(3), 169.

Dumazedier, J. (1974). Prominent Recreationist Defines Leisure. Recreation Canada, 32-55.

Dumazedier, J. (1974). Leisure and the social system. In J. F.Murphy (ed.) Concepts of Leisure, Englewood Cliffs, NJ, Prentice-Hall.

Dumazedier, J. (1967). Toward a society of leisure. New York: FreePress.

Edginton, C. R., Donald D., Rodney D. veSusan E. (2002). Leisure and life satisfaction: foundational perspectives (3rd ed.). N.Y., McGraw-Hill.

Edwards, J. R. ve Nancy, P. R. (2000). Mechanism linking work and family: clarifying the relationship between work and family constructs. Academy of Management Review, 25(1), 180.

Etzion, D., Dow, E. ve Lapidot, Y. (1998). Relief from job stressors and burnout: reserve service a sarespite. Journal of Applied Psychology, 83, 577-585.

Faunce, W. A.,\& Robert D. (1975). Individual investment in Working And Living. In Champoux, J. E. (1978). Perceptions of work and nonwork. Sociology of Work. And Occupations, 5(4), 403.

Fenech, M. A. (2008). Why leisure occupations are a necessary, meaningful and therapeutic use of free time for Individuals with complex neurological disabilities. Researchgate, 1-24.

Gavarkovs, A. G. (2015). Nature-Based physical activity advertising: western undergrate research recommendations based on attention restoration theory and psychoevolutionary theory. Journal Health And Natural Sciences, 6(1), 3.

Gervais, R. L. (2014). Detachment and recovery after work: an overview. Health \& Safety Laboratory, UK.

Geurts, S. ve Sonnentag, S. (2006) Recovery as an explanatory mechanism in the relation between acute stres reaction sandchronic health impairment. Scandinavian Journal of Work, Environment \& Health, 32, 482-492.

Godbey, G. C., Linda, L. C., Myron F. ve Laura, L. P. (2005). Contributions of leisure studies and recreation and park management research to the active living agenda. American Journal of Preventive Medicine, 150-158.

Gorman-Murray, A. ve Catherine, N. (2016). Introduction: sex, consumption and commerce in the contemporary city. Urban Studies, December 6.

Gürbüz, B. ve Karla, H. (2013). Exploring the meanings of leisure among turkish university students. Croatian Journal of Education. Vol. 15(4), 927-957.

Henderson, K. A., Jacqelyn, P. ve Deborah, M. B. (2004) Theory in recreation and leisure research: reflections from the editors. Leisure Sciences, 26, 411-425.

Henderson, K. A. ve M. Deborah B. (2007). Leisure and active lifestyles: research reflections. Leisure Sciences, 355-365.

Hobfoll, S. E. (1989). Conservation of resources a new attempt at conceptualizing stress. American Psychological Association, 44(3), 513-524.

Hobfoll, S. E. (2002). Social and psychological resources and adaptation. Review of General Psychology, 6, 307-324.

Iso-Ahola, S. E. (1989). Motivation for leisure. In E. L. Jackson and T. L. Burton, Understanding Leisure and Recreation. State College, PA.

Iwasaki, Y. ve Roger, C. M. (2000). The effects of leisure beliefs and coping strategies on stress health relationships. Leisure/Loisir, 24(1), 3-57.

İyem, C. (2011). Yeni çalssma etigi ve bos zaman calssanlar: Türkiye'deki profesyonel futbolcular örneği. (Doktora Tezi), Sakarya.

Judge, T. A. ve Shinichiro W. (1994). Individual differences in the nature of th erelationship between job and life satisfaction. The British Psychological Society, 101-107.

Kando, T. M. ve Worth, C. S. (1971). The impact of work on leisure. Pacific Sociological Review, 14, 313-327.

Kaplan, S. (2001). Meditation, restoration and the management of mental fatigue. Environment and Behavior, 33, 8. 
Kaplan, R. veStephan K. (1989). The Experience Of Nature: A Psychological Perspective. Cambridge: Cambridge University Press.

Kanfer, R., Philip, L. A., Todd, C. M., Brad D. ve Leissa N. (1994). Goal setting, conditions of practice, and task performance: a resource allocation perspective. Journal of Applied Psychology, 79, 826-835.

Kelly, J. R. (1972). Work and leisure: a simplified paradigm. Journal of Leisure Research, Vol. 4(1), 50-62.

Kelly, J. R. (1983). Leisure identities and interactions. London: George Allen \& Unwin.

Kelly, J. R. (1997). Changing issues in leisure-family research-again. Journal of Leisure Research, 29(1), 132-134.

Kelly, J. R. ve Janice, R. K. (1994). Multiple dimensions of meaning in the domains of work, family and leisure. Journal of Leisure Research, 26(3), 250-274.

Kelly, J. R. ve Valeria, J. F. (2000). 21st Century Leisure: Current Issues. 79, Boston: Allyn\&Bacon.

Kılbaş, S. (2010). Rekreasyon bos zaman değerlendirme. 4. Basım, Ankara, Gazi Kitabevi.

Kirchmeyer, C. (2002). Nonwork participation and work attitudes a test of scarciity expansion models of personel resources. Human Relations, içinde, Raphael S., Itzhark H., (2002) Work- leisure relations, leisure orientation and the meaning of work. Journal of Leisure Research, 34, 3-43.

Kleiber, D. A., Susan, L. Hutchinson, \& Williams, R. (2002). Leisure as a resource in transcending negative life events; self protections, self restoration and personel transformation. Leisure Science, 24, 219-235.

Lambdin, L. (1997). Elderlearning. Phoenix, AZ: Oryx Express.

Lebbon, A. R. ve Dene T. H. (2012). The effects of workplace leisure behavior on work-related behavior. Journal Of Behavioral Studies In Business, 1-18.

Lee, Y. ve Jim D. (1994). The complex and dynamic nature of leisure experience. Journal of Leisure Research, 26(3), 195211.

Lewis, S. (2003). The integration of paid work and the rest of life. is post-industrial work the new leisure?. Leisure Studies, 22, 343-355.

LM, V., Sabine G. ve Toon, V. T. (2005). Disentangling the causal relationships between work-home interference and employee health. Scandinavian Journal of Work, Environment \& Health, Vol. 31, 15.

Long, J. (1988). Immaculate Concepts?. Paper to the 2nd International Conference of the Leisure Studies Association, University of Sussex, Brighton, England.

Lu, C.-C., Tien-M. C. ve Shu, J. H. (2015).The impact of the causality between work-family conflict, well-being and leisure coping strategies on tour professionals. Journal of Travel \& Tourism Marketing.

Mannell, R. C., \& Douglas A. K. (1997). A social psychology of leisure. Venture Publishing.

McEwen, B. (2006). Protective and damaging effects of stress mediators: central role of the brain. Dialogues Clinic Neuroscience, 8, 363-367.

Meijman, T. F. ve Mulder, G. (1998). Psychological aspects of workload.

Moorhouse, H. F. (1989). Models of Work. Models of Leisure. In C. Rojek, Leisure For Leisure: Critical Essays, London: MacMillan.

Neumeyer, H. M. ve Esther S. N. (1958). Leisure and recreation. Newyork: Ronald Press.

Newman, D. B., Louis, T. ve Ed, D. (2014). Leisure and subjective well-being: a model of psychological mechanisms as mediating factors. Journal Of Happiness Study, 15, 555-578.

Okumuş, E. (2005). Boş zamanlar ve islam. Sosyal Bilimler Araştırma Dergisi, Mart Sayı 5, 26.

Önder, D. (2013). Changing Geography of Urban Leisure: The Case Of Ankara. (Doctor of Philosophy In City and Regional Planning), Ankara.

Özcan, B. (2015). Hedonizm ve Kimlik Temeline Dayalı Postmodern Tüketim Yaklaşımı, http:/ /istanbul.dergipark.gov.tr/ Erişim Tarihi 16/04/2015.

Parker, R. S. (1976). The sociology of leisure. London: Allen \& Unwin.

Pennonen, M. (2011). Recovery From Work Stress Academic Dissertation, University of Tampere Antecedents, Processes And Outcomes. Academic Dissertation University of Tampere, 15.

Roberts, K. (2000). The impact of leisure on society. World Leisure Journal, 3, 6.

Rojek, C. (2010). Leisure and life politics. Leisure Sciences, 115-125.

Rojek, C. (1997). Leisure theory: retrospect and prospect. Loisir \& Societe (Society and Leisure), 20(2), 383-400.

Rojek, C. (1990). Baudrillard and leisure. Leisure Studies, 16, 7-20.

Rojek, C. (1989). Leisureforleisure: Critical Essays. London: MacMillan.

Russell, R. V. ve Frances K. S. (1996). Leisure as burden: sudanese refugee women. Journal of Leisure Research, 28(2), 108-121.

Scraton, S. ve Beccy, W. (1998). Gendered cities: women and public space in the postmodern city. Leisure Studies, 17, 123-137.

Scoot, M. (1995). Zaman Yönetimi. (Çev: Aslı Çıngıl Çelik), İstanbul: Rota Yayınları.

Shamir, B. (1983). Some antecedents of work-nonwork conflict. Journal of Vocational Behavior, 23, 98-111.

Sluiter, J. K., Van der B. ve Monigue, F. D. (1999). The influence of work characteristics on the need for recovery and experienced health: a study on coach drivers. Ergonomics, 42, 573-583.

Sluiter, J. K., Frings, D., Theo, M. ve Van der Beek, A. (2000). Reactivity and recovery from different types of work measured by catecholamines and cortisol: asystematic literature review. Occupational Environmental Medicine, 57, 289-315. 
Sonnentag, S. (2001). Work recovery activities and individual well-being: a diary study. Journal of Occupational Health Psychology, 6, 196-210.

Sonnentag, S. ve Charlotte F., (2007). The recovery experience questionnaire: development and validation of a measure for assessing recuperation and unwinding from work. Journal of Occupational Health Psychology, 12, 204 221.

Stebbins, R. A. (1982). Serious Leisure: A Conceptual Statement. Pacific Sociological Review, 25, 251-272.

Stebbins, R. A. (2012). Homo otiosus: who is this creature, does it exist, should it matter. Leisure Studies Association Newsletter, 94, 19.

Stewart, W. P. (1998). Leisure as multiphase expereinces: challenging traditions. Journal of Leisure Research, 30(4), 391400.

Tait, M., Margaret Y. P. ve Timothy, T. B. (1989). Job and life satisfaction: a reevaluation of the strength of the relationship and gender effects as a function of the date of the study. Journal of Applied Psychology, 74(3), 502-507.

Tel, M. (2007). Ögretim Üyelerinin Boş Zaman Etkinlikleri Üzerine Sosyolöike Bir Arastırma: Doğu Anadolu Örnegi. (Doktora Tezi).

Trougakos, J. P., Daniel, J. B., Stephen G. G. ve Howard, M. W. (2008). Making the break count: an episodic examination of recovery activities, emotional experiences and positive affective displays. Academy Of Management Journal, 18.

Ulrich, R. S., Ulf, D. ve Beverly, L. D. (1989). Psychophysiological indicators of leisure benefits, rocky mountain forest and range experiment station. In B. L. Driver, P. J. Brown, G. L. Peterson, Benefits of leisure. State College, PA: Venture.

Wagner, S. L., John, W. L. ve Lane, G. F. (1989). Attributes factors associated with work/leisure perceptives. Journal Of Leisure Research, 21(2). 155-166.

Westman, M. (1999). Gain and loss spirals: applying hobfoll's cor theory to respite research chicago. Paper Presented At The Academy Of Management Meeting.

Wilensky, H. L. (1960) Work, careers, and social integration. International Social Science Journal, 12(4), 543-560.

Wilson, J. (1980) Thesociology of leisure. AnnualReview of Sociology, 6, 21-40.

Zijlstra, F. R. H. ve Sabine S. (2006). After work is done: psychological perspectives on recovery from work. European Journal of Work and Organizational Psychology, 15, 129-138.

\section{EXTENDED ABSTRACT}

The management of leisure behaviors is one of the important issues in organizations that organization managers often neglect but are related to employee performance. Leisure behaviors were investigated through the perspective of social psychology in this study. How organizational managers hold evaluate leisure behaviors at workplace? The answer of this question constitutes one of the basic aims of this work. And the other question is the reason why employees want to constitute leisure on the job. If the reasons for the employee's desire to constitute leisure in working hours are determined, the leisure behaviors of the employees will be managed successfully. So, performance of the employees will be positively affected. There are different reasons why employees want to create leisure time during workplace. These are given below; 1-)Employee desire to distract from negative job-related events for a short time, 2-) Employee desire to move away from the stressful environment and to renew their own resources which are emotions, energy and other spiritual resources, 3-) Employee perceive his/her job as a low level of difficulty, not creative, not developable and does not require to struggle, 4-) Employee cannot get away from his/her private life and his family problems. In this study, the reasons why employees want to create leisure time are explained with reference to conservation of resources theory, effort recovery model, and attention restoration theory.

Workplace leisure behaviors interrupt the employee's work relationship in a short period of time and that interruption reduces tension of employees, provide short-term escapes from work relax and develop employees, and have a positive effect on job performance. Kanfer, Ackerman, Murtha, Dugdale and Nelson (1994, p. 826) noted that frequent taking a break in jobs with performance targets can achieve higher performance than those not given. Trougakos, Beal, Green and Weiss (2008, p. 18) found that workers in the service sector had high positive feelings at the workday break times. The effect of out of workplace leisure behaviors is explained through the concept of recovery. Meijman and Mulder (1998, p. 8) described recovery as the process by which human functions become normal pre-stress states. Zijlstra and Sonnentag (2006, p. 131) looked at the recovery process from the psychological perspective of the employees and they defined recovery as the situation of the employees being ready to do their present and future jobs. The intensive working hours reveal the need for rest and recovery at work and out of work. Relaxation and recovery occurs daily in coffee breaks, lunch breaks, the use of time between work transitions and the leisure time that occurs at work (Pennonen, 2011, p. 15). In the end of the study, organizational managers should provide their employees with various opportunities through leisure 
activities. These opportunities develop physical and mental capacities that enhance commitment, cooperation and friendship. In addition, suggestions which are given to organization managers are presented below; 1-) The concept of workplace leisure behaviors should be handled with a holistic approach in organizations, especially the reasons of workplace leisure behaviors should be investigated at individual and organization level, 2-) If it is determined that dissatisfaction at work is caused by the leisure behaviors in the workplace, issues of person organization - person job fit should be re-evaluated in the organizations, 3-) The deficiencies in the work processes and job analysis are reason for the leisure behaviors in workplace. So job analysis and work processes should be studied in detail in the organizations. In the future works, workplace and out of workplace leisure behaviors can work with the issue of burn out and stress. Issue of workplace and out of workplace leisure behaviors can be worked through qualitative research. And the results can be compared with the results of this study. 